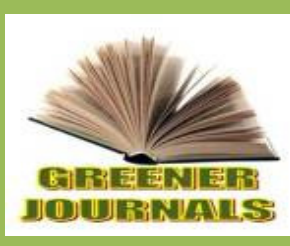

\title{
Bioconversion of Methionine Supplemented Spent Sorghum Mash into Protein Biomassusing Rumen Liquor as Inoculum
}

\section{*Ndams SS, Jahun MB, Ibeh JI, Makeri HK and Ibrahim MM}

College of Agriculture and Animal Science, Ahmadu Bello University, Mando Rd. Kaduna. Nigeria.

Article No.: 022616045

DOI: 10.15580/GJAS.2016.3.022616045

\section{Submitted: $26 / 02 / 2016$}

Accepted: 07/02/2016

Published: 28/03/2016

*Corresponding Author

Ndams SS

E-mail: Samuel_ndams@yahoo

.com

Phone: +2348086183938

Keywords:

Spent Sorghum Mash,

Methionine, Inoculum,

Fermentation
Four (4) samples of Spent Sorghum mash (SSM) with substrate to inoculums concentration of $10: 1(\mathrm{w} / \mathrm{w})$ were supplemented with $0.29,0.33,0.37$, and $0.41 \%$ levels of methionine on dry matter(DM) basis. The same quantity of samples were compacted in four (4) jam bottles of equal volume to achieve anaerobic condition as much as possible and allowed to ferment for 4 days. The re-fermented spent sorghum mash (RSSM) samples were sun-dried for 3 days and subjected to analyses for proximate nutrient and amino acid compositions respectively.The DM\% composition of SSM sample was significantly $(P<0.05)$ higher than samples on 0.29 , 0.33 and $0.39 \%$ methionine treatments. The crude Protein content of all samples on $0.29,0.33,0.39$ and $0.41 \%$ methionine treatment did not differ significantly $(P>0.05)$ but were significantly $(\mathrm{P}<0.05)$ higher than the control. The $\mathrm{CP} \%$ was observed to increase linearly with increase in the levels of methionine supplementation. The CF\% composition of sample on control were similar to that on $0.29 \%$ methionine treatment but significantly $(P<0.05)$ higher than that on $0.33,0.37$, and $0.41 \%$ methionine treatments. The RSSM sample showed the availability of all essential amino acids except tryptophan (alanine, arginine, glycine, histidine, isoleucine, leucine, lysine, methionine, phenylalanine, threonine and valine). The results of this study indicates increase in quantity of protein and the availability of essential amino acids after second stage fermentation of spent sorghum mash with methionine supplementation and can therefore be used in rations for non-ruminant animals in place of expensive conventional plant protein sources. 


\section{ABBREVIATIONS}

1. $\mathrm{SSM}=$ Spent sorghum mash

2. $\mathrm{RSSM}=\mathrm{Re}$-fermented spent sorghum .

3. $\mathrm{CF}=$ Crude fibre

4. $\quad \mathrm{CP}=$ Crude protein

5. $\mathrm{NFE}=$ Nitrogen Free extract

6. $A O A C=$ Association of Official Analytical Chemists

\section{INTRODUCTION}

In Nigeria today, most consumers are not able to afford the market prices of chicken meat and eggs. This is largely due to high production cost of these foods. The major problem for producers is the shortage and high cost of feed ingredients. This has prompted researchers to seek protein production from unconventional sources. One promising unconventional source is the mass cultivation of microbial biomass using renewable substrate which occur abundantly in nature (Ofuya and Obilor, 1993). In Solid state fermentation, the growth of microorganisms and products formed occurs at the surface of the solid substrate. The substrate supplies the energy needed for microbial growth and products formation. The use of fermentation process to produce microbial biomass according to Yalemstesfa et al. (2010) has several advantages over others for the fact that fermentation processes are not subject to the variability of weather conditions and can be controlled for product quantity and quality in any geographical location. And according to Rudravaram et al. (2006), production of microbial proteins by fermentation of agricultural waste products is one of the most promising approaches for increasing the availability of protein. The nutrients of food waste may be re-used in agriculture by transformation of food waste into animal feed. One of such food waste is sorghum spent mash (SSM). Its usage in poultry nutrition has been evaluated by many researchers (Ndams, 1991; Ayodeji and Fasuyi, 2005; Demeke, 2007; and Pousga et al., 2007) and its inclusion at higher levels in poultry diets has yielded negative responses because of its high fibre levels which reduces nutrients utilization and resulted in growth depression (Udedibie and Emanalom, 1993). This study was aimed at evaluating the possibility of improving the protein quantity and quality of SSM for re-use under solid substrate fermentation using rumen liquor as inoculum.

\section{MATERIALS AND METHODS}

\subsection{Experimental site}

The 2nd stage fermentation was carried out at the Student Project Site of the Poultry Production Unit, College of Agriculture and Animal Science, Mando-Kaduna, Nigeria (110 10' N, 07038'E with elevation of 632m above sea level with an average rainfall of $1200 \mathrm{~mm}$ with $95 \%$ falling between April and October. The temperature varies between $26-35 \mathrm{oc}$. The humidity at harmattan period is 21 and $27 \%$ at the wet season. Mando is Located in the Northern Guinea savannah Zone of Nigeria(Google maps, 2015).

\subsection{Sources and nature of spent sorghum mash (SSM)}

The SSM used in this experiment was the red sorghum spent mash. It was characteristically reddish in colour and appears fibrous. Dried samples are odorless with sour taste. All samples used in this experiment were purchased dried from the traditional 'Burukutu' brewers around Kaduna metropolis.

\section{$2.3 \quad$ Inoculum preparation}

Rumen content of cow was collected fresh just after slaughter at the Sabon-Tasha abattoir, Kaduna. This was then mixed with water in a 2:1 ratio on a weight by weight $(\mathrm{w} / \mathrm{w})$ basis and filtered through a mosquito net of pore size 2.78mm2 (Ndams et al., 2011). The residue was discarded and the filtrate used as inoculum.

Four (4) SSM samples of same substrate to inoculums concentration $(10: 1)$ were treated with the following levels of methionine on dry matter basis; 0.29 , $0.33,0.37$, and $0.41 \%$ (Fazaeli et al., 2007) before refermentation for four days. The levels of methionine required for the treatment of $500 \mathrm{~g}$ of SSM were as follows: $1.45,1.65,1.85$ and $2.00 \mathrm{mg}$. The different ratios used were as presented in Table 1.

Methionine was first dissolved in the water and the inoculum introduced before SSM samples were wetted. The $500 \mathrm{~g}$ SSM Methionine treated samples were compacted in jam bottles and fermented for 4 days. 
Table 1: Ratio of methionine to water, to inoculum, and to substrate

\begin{tabular}{lcccc}
\hline Sample & methionine $(\mathbf{m g})$ & Water $(\mathbf{g})$ & Inoculum $(\mathbf{g})$ & SSM \\
\hline & & & & \\
A & 1.45 & 2500 & 50 & 500 \\
B & 1.65 & 2500 & 50 & 500 \\
C & 1.85 & 2500 & 50 & 500 \\
D & 2.00 & 2500 & 50 & 500 \\
\hline
\end{tabular}

\section{$2.4 \quad$ Fermentation}

Each inoculated SSM sample was properly compacted in the bottle to exclude any possible air. The mouth of the bottles were covered with polythene materials and finally sealed with covers so as to maintain anaerobic condition as much as possible. All bottles of the inoculated SSM samples were labeled accordingly and allowed to ferment for 4 days.

\subsection{Proximate analysis}

After 4days of fermentation, the methionine - treated and re-fermented spent sorghum mash (RSSM) were removed from the bottles and sun-dried for 3 days after which samples were taken for chemical analysis at the Department of Animal Science, Faculty of Agriculture, Ahmadu Bello University, Zaria-Nigeria. The proximate determination for dry matter (DM), crude protein (CP), crude fibre (CF), ether extract (EE), ash and nitrogen free extract (NFE) were carried out. NFE was calculated by difference. The analytical procedures for DM, CF, CP, EE, Ash and NFE determinations employed in this experiment were in accordance with AOAC (2000). The determination of amino acids profile in SSM and re-fermented spent sorghum mash (RSSM) were carried out at the Department of Zoology, University of Jos using methods described by Sparkman et al. (1958)

\subsection{Data analysis}

Data collected were subjected to Analysis of variance procedure (ANOVA-Single factor) using "Analyse-it" for Microsoft Excel (3.03) Standard. Significant means were separated using the Duncan Multiple Range Test (1995) taking $P<0.05$ as level of significance.

\section{RESULTS}

Table 2 shows the effect on nutrient composition of methionine treated and fermented SSM samples. The $\mathrm{DM} \%$ composition of the control sample compared to that on $0.41 \%$ methionine treatment was similar but significantly $(P<0.05)$ higher than those on $0.29,0.33$ and $0.39 \%$ methionine treatment which all had similar DM composition. The CP\% was observed to increase linearly with increase in the levels of methionine supplementation (figure 1). The crude Protein content of all samples on 0.29 , $0.33,0.39$ and $0.41 \%$ methionine treatment did not differ significantly $(P>0.05)$ but were significantly $(P<0.05)$ higher than the control. The CF\% composition of sample on control were similar to that on $0.29 \%$ methionine treatment but significantly $(\mathrm{P}<0.05)$ higher than those on $0.33,0.37$, and $0.41 \%$ methionine treatments.

The percentage ether extract (EE \%) of the control sample was significantly the $(P<0.05)$ lowest compared to those samples on $0.29,0.33,0.37$ and $0.41 \%$ methionine treatments. Samples on $0.29 \%$ methionine treatment was significantly $(P<0.05)$ the highest. Samples on $0.33 \%$ methionine treatment was significantly $(P<0.05)$ higher than those on 0.37 and $0.41 \%$ methionine treatment but significantly $(\mathrm{P}<0.05)$ lower than $0.29 \%$ In terms of percentage ash, samples on $0.29 \%$ treatment was significantly $(\mathrm{P}<0.05)$ higher than all the samples on 0.33 , $0.37,0.41 \%$ methionine treatment and the control. 0.33, and $0.41 \%$ methionine treated samples were similar $(P>0.05)$ while 0.37 and $0.41 \%$ methionine treated samples were similar also.

The amino acid profiles of SSM and all RSSM samples revealed the availability of all essential amino acids except tryptophan (alanine, arginine, glycine, histidine, isoleucine, leucine, lysine, methionine, phenylalanine, threonine and valine) in the samples. The amino acid concentrations ( $g / 100 \mathrm{~g}$ protein) of all the essential amino acid of the RSSM samples were higher than those of SSM (Table 3). 
Table 2: Proximate composition (\%) of methionine treated and fermented sorghum spent sorghum mash

\begin{tabular}{lcccccc}
\hline \multicolumn{2}{l}{ Level of methionine supplementation (\%) } \\
\cline { 2 - 7 } Parameters (\%) & $\mathbf{0}^{\mathbf{1}}$ & $\mathbf{0 . 2 9}$ & $\mathbf{0 . 3 3}$ & $\mathbf{0 . 3 7}$ & $\mathbf{0 . 4 1}$ & SEM $^{\dagger}$ \\
\hline Dry matter, & $91.72^{\mathrm{a}}$ & $89.66^{\mathrm{bc}}$ & $89.7^{\mathrm{bc}}$ & $90.20^{\mathrm{b}}$ & $91.88^{\mathrm{a}}$ & 0.47 \\
Crude protein, & $21.73^{\mathrm{b}}$ & $24.91^{\mathrm{a}}$ & $25.15^{\mathrm{a}}$ & $25.31^{\mathrm{a}}$ & $25.56^{\mathrm{a}}$ & 0.71 \\
Crude fibre, & $14.49^{\mathrm{a}}$ & $14.73^{\mathrm{a}}$ & $12.3^{\mathrm{bc}}$ & $12.89^{\mathrm{b}}$ & $12.16^{\mathrm{c}}$ & 0.66 \\
Ether extract, & $1.20^{\mathrm{d}}$ & $3.43^{\mathrm{a}}$ & $2.97^{\mathrm{b}}$ & $2.38^{\mathrm{c}}$ & $2.14^{\mathrm{c}}$ & 0.38 \\
ASH, & $24.36^{\mathrm{b}}$ & $26.86^{\mathrm{a}}$ & $22.31^{\mathrm{c}}$ & $20.61^{\mathrm{d}}$ & $21.44^{\mathrm{cd}}$ & 1.30 \\
Nitrogen free extract, & $37.43^{\mathrm{b}}$ & $32.61^{\mathrm{d}}$ & $37.66^{\mathrm{b}}$ & $38.89^{\mathrm{a}}$ & $36.15^{\mathrm{c}}$ & 1.07 \\
\hline
\end{tabular}

$a, b, c, d$ Means of the same row with different superscripts are significantly different $(P<0.05)$

*Values represent averages of three determinations per sample

${ }^{1}$ Unfermented spent sorghum mash (control)

tStandard error of mean

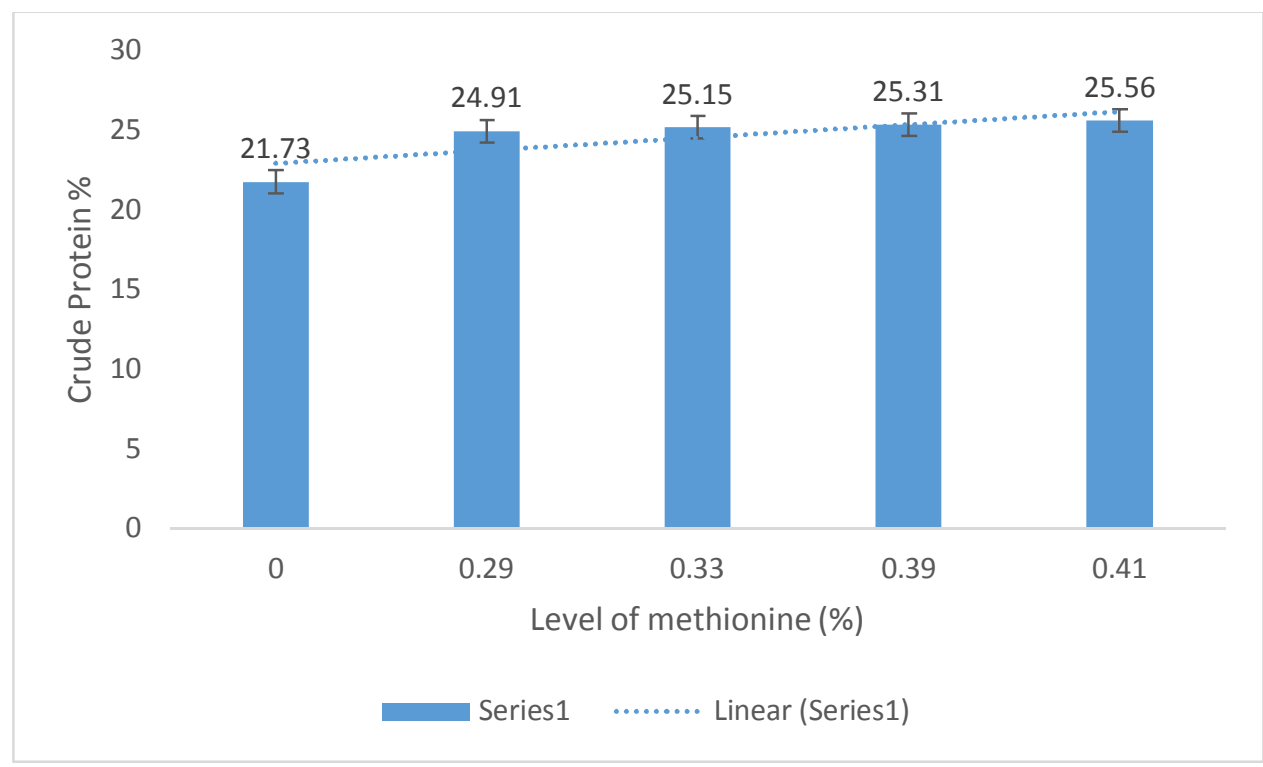

Figure 1: Effect on crude protein yield of fermented methionine supplemented SSM sample 
Table 3: Amino acid profiles of SSM and highest RSSM Protein produced ( $25.56 \%$ CP)

\begin{tabular}{lll}
\hline $\begin{array}{l}\text { Amino acid composition } \\
\text { (g/100g protein) }^{\mathrm{a}}\end{array}$ & SSM & RSSM \\
\hline Alanine & 8.66 & 8.51 \\
Arginine & 4.66 & 4.31 \\
Cysteine & 2.18 & 1.85 \\
Glycine & 3.17 & 2.88 \\
Histidine & 2.40 & 2.21 \\
Isoleucine & 4.18 & 3.74 \\
Leucine & 13.71 & 13.22 \\
Lysine & 2.38 & 2.32 \\
Methionine & 1.93 & 1.88 \\
Phenylalanine & 5.15 & 4.98 \\
Threonine & 3.48 & 3.21 \\
Tyrosine & 4.13 & 3.81 \\
Serine & 4.56 & 4.29 \\
Valine & 5.27 & 5.04 \\
\hline
\end{tabular}

${ }^{a}$ values represents averages of two determinations per sample

\section{DISCUSSION}

The fermentation of methionine supplemented SSM resulted in increased crude protein from $21.73 \%$ before to a peak of $25.56 \%$ after fermentation. The increase in \%CP of RSSM samples with different levels of methionine supplementation in this study over the control is in agreement with the report of Stevani et al. (1992) that rumen bacteria utilized sulphur amino acids for bacteria protein synthesis. In this case, methionine served as a source of Sulphur (S) for microbial protein synthesis. Sulphur is said to be an essential micro-mineral essential for the formation of Sulphur containing compounds in the body (Bal and Ozturk, 2006). Studies have shown that Sulphur supplementation has improved gain by $12 \%$ in steer grazing sorghum-Sudan grass containing 0.08 $0.12 \%$ methionine (Anonymous, 1998). The similarity in $\% \mathrm{CP}$ for all fermented methionine supplemented samples are in agreement with the findings of Brondani et al. (1991), that the effect of methionine supplementation on bacteria protein synthesis from high fibre nitrogen $(\mathrm{N})$ based diets will depend on its adjustment based on the $\mathrm{N}$ : S ratio. If the level of nitrogen in the diet remain low, the effect of increasing levels of $S$ on bacteria protein synthesis will remain insignificant. The availability of essential amino acids in the unfermented (SSM) and fermented methionine - supplemented spent sorghum mash(RSSM)is an indication that RSSM samples can serve as protein sources in poultry nutrition (McDonald et al., 1998). Methionine is a Sulphur amino acid which is used in the synthesis of Sulphur amino acids in the body of an animal. The amino acid profile of RSSM samples was inferior to the control (SSM). This is in agreement with Spear et al., (1978) who observed numerical decrease in essential amino acids in lambs fed tall fescue supplemented with I- methionine Sulphur at 0.05 and $0.15 \%$ compared to the control $(0 \%)$.

\section{CONCLUSION}

It could be concluded in this study that 4days fermentation of spent sorghum mash with methionine supplementation improves protein quantity with available essential amino acids that could serve as alternative protein ingredient in non-ruminant diets.

\section{AUTHORS' CONTRIBUTIONS}

- The authors after the study was proposed to them participated in the conception and design of the study.

- Assistance was also received in the area of data graphical interpretation and in the editing of the manuscript for publishing

\section{ACKNOWLEDGEMENTS}

The authors acknowledge the assistance of Mr. Ibrahim Kwano of the Chemical Laboratory, Department of Animal Science, Ahmadu Bello University, Zaria, Nigeria for proximate chemical analysis and Dr Titus Ojobe of the Department of Zoology, University of Jos,Nigeria for the determination of amino acid profiles of SSM and RSSM samples. 


\section{REFERENCES}

Association of Official analytical Chemists (2000). Official methods of analysis, $15^{\text {th }}$ ed. AOAC, Arlington, Virginia, U.S.A, Pp. 12-98.

Ayodeji, O and Fasuyi, (2005). Maize-sorghum based brewery By-products as an energy substitute in broiler starter diets. International J.Poult.Sci.4 (5); 334-338.

Bal, M.A. and Ozturk, D. (2006). Effects of Methionine Containing Supplements on Ruminal Fermentation and Microbial Protein Synthesis. Research J. Anim. and Vet. Sci.1(1): 33-36.

Brondani, A., R. Towns, K. Chou, and R.M. Cook, (1991). Effects of isoacids, urea, and methionine on ruminal fermentation in sheep fed high fiber diets. J.Dairy Sci. $74: 2724$.

Demeke, S. (2007). Comparative nutritive value of Atella and industrial brewers grains in chicken starter ration in Ethiopia. Livestock Research for Rural

Development. 19 (1)http://www.cipav.Org.co/Irrd19/1/deme19008.htm.

Duncan, D.B, (1995). New Multiple Range and Multiple FTest. Biometrics 11: 1-42.

Fazaeli, H., Mashsyekhi, M. R. and Mansouri, H. (2007). Effect of Nitrogen-Methionine ratio on the digestibility of roughage based diet incubated with rumen liquor of buffalo. Ital.J.Anim.Sci.6, (2): 450-

45.HTTPS://www.googlemaps.com.

McDonald P., Edwards, R.A., Greenhalg, J.F.D. and Morgan, C.A. (1998). Animal Nutrition (5th ed). London Longman GRP. Ltd. Pp. 623.

Ndams, S. S. (1991). Comparative Evaluation of Refermentated Spent Sorghum Mash and Cotton Seed cake as Protein Sources of Broiler Poultry Rations. B. Agric. Tech. (Hons). Thesis, A.T.B.U. Bauchi. Pp 63.

Ndams, S. S., Tegbe, T.S.B., Ogundipe, S.O. and Sheyin, Z. (2011). Determination of the optimum inoculums concentration and fermentation period and their effect on nutrient composition of Brewers dried grains. Sci. World J.6 (1): 13-19.

Ofuya, C.O. and Obilor S.N. (1993): The suitability of fermented cassava peel as a poultry feedstuff. Bioresources Technol. 44:101-104.

Pousga, S., Boly, H., Lindberg, J.E. and Ogle, B. (2007). Evaluation of Traditional Sorghum Beer Residue, Shea-Nut (Vitellaria paradoxa) Cake and Cottonseed (Gossypium Spp) Cake for Poultry in Burkina Faso: Availability and Amino Acid Digestibility. Int. J. Poult. Sci. 6(9): 666-672.

Rudravaram, R., Chandel, A. K, Linga V. R, Pogaku, R. (2006). Optimization of protein enrichment of deoiled rice bran by solid state fermentation using Aspergillus oryzae MTCC 1846. Int. J. Food Engng. 2:1-14.

Sparkman, D.H., Stein, E.H. and Moore, S. (1958). Antinutritive recording apparatus for use in thechromatography of amino acid analytical chemistry.30: 1190-1191.

Spear, J. W., Ely, D. G. and Bush, L.P. (1978). Influenced of supplemental methionine on in vitro and inVivo Microbial Fermentation of Kentucky 31 Tall Fescue. J. Anim. Sci.47: 552-560.

Stevani, J., Duranal, M., Zanchi, R., Beaumatin, P., Hannequart, G. (1992). Effect of sulphate supplementation of untreated and alkali-treated wheat straws on ruminal fermentation and microbial protein synthesis in a semi-continuous fermenter. Anim. Feed Sci. Technol. 36:287-301.

Udedibie, A.B.I and Emanalom, O.O. (1993). Preliminary observations on the use of Maize sorghum based brewers grains fortified with palm oil for finishing broilers. Nig. J. of Anim. Prod. 20 (1\&2): 104-110.

Yalemtesfa, B., Tesfaye, A and Santhanam, A. (2010). Solid substrate fermentation and conversion of orange waste in to fungal biomass using Aspergillus niger KA06 and Chaetomium Spp KC-06. African. J. Microbiol. Res.4 (12): 1275- 1281. 